\title{
Water soluble phosphorus in Finnish mineral soils and its dependence on soil properties
}

\author{
HELINÄ HARTIKAINEN
}

Department of Agricultural Chemistry, University of Helsinki, $00710 \mathrm{Hel}$ sinki 71

\begin{abstract}
Water soluble phosphorus ranged from $0.2 \mathrm{mg}$ to $117.8 \mathrm{mg} / \mathrm{kg}$ in 104 surface soil samples studied. On the average, water extracted less $P$ from the heavy clay soils $(4.8 \pm 2.2 \mathrm{mg} / \mathrm{kg})$ than from the coarser clays $(12.8 \pm 4.6 \mathrm{mg} / \mathrm{kg})$ and non-clay soils $(13.3 \pm 7.2 \mathrm{mg} / \mathrm{kg})$.

Water extraction seemed to illustrate "the effective" P status, it is that determined by the quantity and quality of sorption components in soil, soil $\mathrm{pH}$ and the content of organic carbon. These factors did not affect the amounts of $\mathrm{P}$ dissolved in water directly but inderectly by controlling the nature of $\mathrm{P}$ bonding which, in turn, seems to be of decisive importance in the extractability of $\mathrm{P}$ into water.

The $\mathrm{P}$ supplying power of a given fraction is obviously controlled by the quantity of corresponding sorption agent. Water extractable $\mathrm{P}$ correlated most closely with the molar ratio of $\mathrm{NH}_{4} \mathrm{~F}$ soluble $\mathrm{P}$ to oxalate extractable $\mathrm{Al}\left(\mathrm{r}=0.93^{\text {H\# }}, \mathrm{n}=103\right)$. However, according to the theory presented, with progressing desorption, $\mathrm{P}$ starts to mobilize also from the $\mathrm{NaOH}$ soluble fraction, its significance being the more apparent the greater the corresponding molar ratio $\mathrm{NaOH}-\mathrm{P} / \mathrm{Fe}$ is. In addition, the role and significance of other inorganic $\mathrm{P}$ fractions were discussed.
\end{abstract}

\section{Introduction}

The availability of soil phosphorus to plants essentially depends on the solubility of phosphorus compounds or surface complexes. A great deal of effort has been expended on trying to find suitable chemical extraction methods for the determination of phosphorus resources in soils available to plants.

In Europe, the lactat method is commonly being used, but recently also the water extraction method of van der PAAUW (1971) and SISSINGH (1971) has become general. According to SCHACHTSCHABEL and BEYME (1980), water soluble phosphorus reflects the quantity of total phosphorus relatively easily dissolved and, thus, the phosphorus supplying power of the soil. In the pot experiment made by AURA (1978) with some Finnish soils, the phosphorus extracted by water quite well correlated with the phosphorus uptake by the oats.

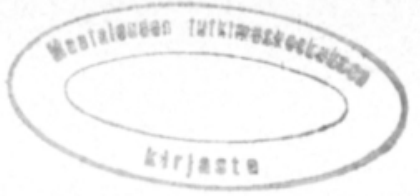


Water treatment is superior to strong extractants, because it does not alter the microstructure of the soil decisively. Further, water soluble, inorganic phosphorus is biologically immediately available and therefore the method can be used also for estimating the ability of eroded soil material to load surface waters with phosphorus or quantities of phosphorus possible to be dissolved in runoff waters.

The purpose of the present study was to investigate the amount of water soluble phosphorus in Finnish mineral soils and its dependence on soil properties. The results were assumed to give intimations also about factors regulating phosphorus exchange between the bottom sediment and overlying water in lakes.

\section{Material and methods}

The material consisted of 104 mineral soil samples from southern and middle Finland. Most of the samples were taken from the plough layer of cultivated soils and only a few ones from the surface layer of virgin soils. All the samples were air-dried and ground to pass a 2 -mm sieve. They were divided into three groups on the basis of the results of mechanical analysis. The heavy clay soils (19) were samples containing $60 \%$ or more clay $(<2 \mu \mathrm{m})$ and the coarser clays (51) those containing 30-59\% clay. The group of nonclay soils consisted of 27 silt soil samples in which the particle size fraction 2-20 $\mu \mathrm{m}$ was dominating and of 7 fine sand soils with the main fraction $20-200 \mu \mathrm{m}$.

The chemical characteristics of the soil samples are presented in Table 1 . Soil pH was measured by a Beckman pH-meter in a $0.01 \mathrm{M} \mathrm{CaCl}_{2}$ suspension in the ratio of 1 to 2.5 . The content of organic carbon was determined by a modified WALKLEY and BLACK wet combustion method (GRAHAM 1948). Amorphous aluminium, iron and manganese were extracted by shaking the samples for two hours in a $0.05 \mathrm{M}$ ammoniumoxalate solution $(\mathrm{pH} 3.3)$ in the ratio of soil to solution of $1: 20(\mathrm{w} / \mathrm{v})$. Aluminium, iron and manganese concentrations were determined by a Varian Techtron atomic absorption spectrophotometer.

The inorganic phosphorus status of the soils was studied by a modified CHANG and JACKSON fractionation method (HARTIKAINEN 1979). The various extracts were analysed for phosphorus by a molybdenum blue method, modified by KAILA (1955). Water soluble phosphorus was extracted by a modified van der PAAUW (1971) and SISSINGH (1971) method. Deionized water was used at a water-soil ratio of 60:1 on volume/weight basis. Premoistening was replaced by prolonged shaking: on hour after addition of water and 15 minutes after standing for 23 hours. The suspensions were centrifuged and filtered through a filter of $0.2-\mu \mathrm{m}$ pore size. The phosphorus concentrations in the filtrates were determined by the ascorbic acid method (ANON. 1969).

\section{Results}

The amount of water soluble P ranged very widely: $0.2-117.8 \mathrm{mg} / \mathrm{kg}$ soil, the average being $11.5 \mathrm{mg} / \mathrm{kg}$ and the median $5.8 \mathrm{mg} / \mathrm{kg}$. Table 2 shows the quantities of water extractable $\mathrm{P}$ and the inorganic $\mathrm{P}$ fractions in the various soil sample groups. The water soluble reserves in the heavy clay soils were generally smaller and ranged less than those in the coarser soils. The total fractionated $\mathrm{P}$ varied from 160 to $1453 \mathrm{mg} / \mathrm{kg}$ soil, the average being $564 \mathrm{mg} /$ kg. As a rule, $\mathrm{NH}_{4} \mathrm{Cl}$ and $\mathrm{H}_{2} \mathrm{SO}_{4}$ extracted less $\mathrm{P}$ from the heavy clay soils than from the samples belonging to the other groups. With regard to the other extractants, the differences between the soil groups were not statistically significant. Only in a few soil samples did the quantity of $\mathrm{NH}_{4} \mathrm{~F}-\mathrm{P}$ ("Al-P") 
Table 1. Chemical characteristics of the soil samples. Means with the confidence limits at the 95 per cent level, $w=$ range.

\begin{tabular}{ccccccc}
\hline & \multirow{2}{*}{$\begin{array}{c}\text { Number of } \\
\text { samples }\end{array}$} & & $\mathrm{pH}$ & Org.C & \multicolumn{3}{c}{ Oxalate extractable $(\mathrm{mmol} / \mathrm{kg})$} \\
\cline { 7 - 8 } & & \% D.M. & $\mathrm{Al}$ & $\mathrm{Fe}$ & $\mathrm{Mn}$ \\
\hline Heavy & 19 & $5.0 \pm 0.2$ & $5.2 \pm 1.0$ & $95 \pm 22$ & $94 \pm 13$ & $1.8 \pm 0.7$ \\
clays & $\mathrm{w}$ & $4.2-6.0$ & $1.0-9.0$ & $45-255$ & $30-149$ & $0.3-5.5$ \\
& & & & & & \\
$\begin{array}{c}\text { Coarser } \\
\text { clays }\end{array}$ & 51 & $5.2 \pm 0.2$ & $4.4 \pm 0.7$ & $63 \pm 7$ & $71 \pm 7$ & $2.9 \pm 0.5$ \\
& $\mathrm{w}$ & $4.3-6.6$ & $0.5-17.4$ & $32-161$ & $24-171$ & $0.6-7.8$ \\
$\begin{array}{c}\text { Non-clay } \\
\text { soils }\end{array}$ & 34 & $5.2 \pm 0.2$ & $3.5 \pm 0.1$ & $60 \pm 10$ & $62 \pm 6$ & $2.4 \pm 0.6$ \\
& $\mathrm{w}$ & $3.8-6.3$ & $0.2-7.7$ & $17-141$ & $33-112$ & $0.4-7.4$ \\
\hline
\end{tabular}

Table 2. Water soluble $\mathrm{P}$ and $\mathrm{P}$ fractions $(\mathrm{mg} / \mathrm{kg})$ in the soil samples. Means with the confidence limits at the 95 per cent level, $w=$ range.

\begin{tabular}{|c|c|c|c|c|c|c|c|}
\hline & \multirow{2}{*}{$\begin{array}{l}\text { Water } \\
\text { soluble }\end{array}$} & \multirow[b]{2}{*}{$\mathrm{NH}_{4} \mathrm{Cl}$} & \multicolumn{3}{|c|}{$P$ extracted sequentially by } & \multirow[b]{2}{*}{$\begin{array}{l}\text { reduct. } \\
\text { solution }\end{array}$} \\
\hline & & & & $\mathrm{NH}_{4} \mathrm{~F}$ & $\mathrm{NaOH}$ & $\mathrm{H}_{2} \mathrm{SO}_{4}$ & \\
\hline Heavy & & $4.8 \pm 2.2$ & $2.0 \pm 0.4$ & $93 \pm 49$ & $264 \pm 47$ & $132 \pm 43$ & $15.0 \pm 5.4$ \\
\hline clays & w & $0.2-20.0$ & $1.0-4.5$ & $14 \pm 490$ & $132-427$ & $39-423$ & $3.0-41.0$ \\
\hline Coarser & & $12.8 \pm 4.6$ & $6.4 \pm 2.4$ & $112 \pm 25$ & $220 \pm 33$ & $214 \pm 25$ & $17.3 \pm 3.3$ \\
\hline clays & $\mathbf{w}$ & $0.2-78.2$ & $0.8-38.6$ & $10-478$ & $36-586$ & $63-423$ & $3.0-57.8$ \\
\hline Non-clay & & $13.3 \pm 7.2$ & $6.7 \pm 3.6$ & $129 \pm 35$ & $204 \pm 36$ & $231 \pm 30$ & $15.5 \pm 2.9$ \\
\hline soils & w & $0.3-117.8$ & $0.8-60.0$ & $13-498$ & $65-487$ & $91-411$ & $5.0-42.8$ \\
\hline
\end{tabular}

exceed that of $\mathrm{NaOH}-\mathrm{P}$ ("Fe-P"). In the heavy clay soils the ratio of $\mathrm{NH}_{4} \mathrm{~F}-\mathrm{P}$ to $\mathrm{NaOH}-\mathrm{P}$ tended to be lower than in the coarser ones.

There was one heavy clay sample containing many times more oxalate soluble $\mathrm{Al}$ than the other samples of the group. This exceptional soil sample was mostly excluded from the statistical analyses.

Water soluble $\mathrm{P}$ seemed to be associated with the total fractionated $\mathrm{P}$ $\left(\mathrm{r}=0.75^{* \%}, \mathrm{n}=104\right)$. However, this correlation gives no information about factors primarily regulating the level of $\mathrm{P}$ soluble in water. The positive relationship is probably due to the fact that the main portion of total $\mathrm{P}$ is composed of fractions supposed to represent secondary phosphates $\left(\mathrm{NH}_{4} \mathrm{Cl}-\mathrm{P}\right.$, $\mathrm{NH}_{4} \mathrm{~F}-\mathrm{P}, \mathrm{NaOH}-\mathrm{P}$ and reductant soluble $\mathrm{P}$ ). Table 3 shows that, excluding the heavy clay soils, the water soluble resources were quite poorly related to the $\mathrm{H}_{2} \mathrm{SO}_{4}-\mathrm{P}$ assumed to represent primary apatite- $\mathrm{P}$. They were most closely connected with the $\mathrm{NH}_{4} \mathrm{Cl}$ extractable fraction and quite well with the $\mathrm{NH}_{4} \mathrm{~F}$ soluble one. They correlated distinctively more poorly with the $\mathrm{NaOH}-\mathrm{P}$, and not at all with the reductant soluble fraction.

The other soil properties studied seemed to have no direct effect on the extractability of $\mathrm{P}$ into water. Only an increase in the soil $\mathrm{pH}$ tended 
Table 3. Total linear correlation coefficients for the relation between water soluble $\mathrm{P}$ and soil characteristics.

\begin{tabular}{|c|c|c|c|c|}
\hline & $\begin{array}{c}\text { Heavy clays } \\
\text { (18) }\end{array}$ & $\begin{array}{c}\text { Coarser clays } \\
\text { (51) }\end{array}$ & $\begin{array}{c}\text { Non-clay soils } \\
(34)\end{array}$ & $\begin{array}{c}\text { All samples } \\
(103)\end{array}$ \\
\hline $\mathrm{pH}$ & $0.48^{*}$ & $0.34^{*}$ & ns & ns \\
\hline $\mathrm{NH}_{4} \mathrm{Cl}-\mathrm{P}$ & $0.68^{\text {*n }}$ & $0.96^{* * 4}$ & $0.97^{w+1 *}$ & $0.96^{\text {*4* }}$ \\
\hline $\mathrm{NH}_{4} \mathrm{~F}-\mathrm{P}$ & $0.62^{* 4}$ & $0.75^{\text {\#\#4 }}$ & $0.80^{\text {\#\#\# }}$ & $0.77^{4+44}$ \\
\hline $\mathrm{NaOH}-\mathrm{P}$ & ns & $0.59^{\# \# \#}$ & $0.53^{* 4}$ & $0.48^{\text {**4 }}$ \\
\hline $\mathrm{H}_{2} \mathrm{SO}_{4}-\mathrm{P}$ & $0.60^{* 4}$ & $0.53^{\text {\#\#\# }}$ & $0.38^{*}$ & $0.47^{\text {\#\#\# }}$ \\
\hline
\end{tabular}

ns $=$ not significant

somewhat to enhance the solubility in the heavy clay soils $(r=0.50 * n=19)$. When the effect of organic carbon was eliminated, the correlation rose to $\mathrm{r}=0.58^{\%}$. In the other soil groups, the relationship between organic carbon and soil acidity was not very distinct, and the values of the partial correlation coefficients remained low.

Some dependence did, however, exist between certain $\mathrm{P}$ fractions and chemical soil properties. In the coarser clay soils, $\mathrm{NH}_{4} \mathrm{Cl}-\mathrm{P}$ was positively, but weakly correlated with $\mathrm{pH}\left(\mathrm{r}=0.44^{\%}, \mathrm{n}=51\right)$. The $\mathrm{H}_{2} \mathrm{SO}_{4}$ soluble reserves seemed to be the greater the higher the soil $\mathrm{pH}$ was, but the values of the correlation coefficients remained quite low. This relationship between $\mathrm{H}_{2} \mathrm{SO}_{4}-\mathrm{P}$ and $\mathrm{pH}$ probably explains to some degree the correlation found between the water soluble $\mathrm{P}$ and $\mathrm{H}_{2} \mathrm{SO}_{4}-\mathrm{P}$; by excluding the effect of $\mathrm{pH}$, the correlation in the heavy clay soils was lowered from $r=0.60 \%$ to $0.48^{*}$ and in the coarser clay soils from $\mathrm{r}=0.53^{* \% *}$ to $0.47 \% * \%$.

The $\mathrm{NH}_{4} \mathrm{~F}-\mathrm{P}$ was not connected with oxalate extractable $\mathrm{Al}$, whereas the oxalate soluble $\mathrm{Fe}$ seemed to some extent to explain the variation in the $\mathrm{NaOH}-\mathrm{P}$ in the heavy and coarser clay soils $(60 \%$ and $56 \%$, respectively), but not in the non-clay soils. On the contrary, the ratio of $\mathrm{NH}_{4} \mathrm{~F}-\mathrm{P}$ to $\mathrm{NaOH}-\mathrm{P}$ correlated moderately with the ratio of $\mathrm{Al}$ to $\mathrm{Fe}$, the value of $\mathrm{r}$ being $0.78^{* *}\left(0.97^{* * *}, \mathrm{n}=19\right)$ in the heavy clay soils, $0.75^{* * *}$ in the coarser clays, $0.47^{*}$ in the non-clay soils and $0.60 \% *$ in all samples. The ratio $\mathrm{NH}_{4} \mathrm{~F}-\mathrm{P} /$ $\mathrm{NaOH}-\mathrm{P}$ was not significantly related to the soil $\mathrm{pH}$. In the heavy clay soils it tended to become greater with an increase in the content of organic carbon $\left(\mathrm{r}=0.58^{* * *)}\right)$.

An interesting finding observed was the tendency the reductant soluble $\mathrm{P}$ fraction being slightly related to oxalate extractable $\mathrm{Fe}\left(\mathrm{r}=0.53^{*}, \mathrm{n}=19\right)$ in the heavy clay soils, and to oxalate extractable $\mathrm{Mn}$ in the coarser clays and nonclay soils $\left(\mathrm{r}=0.63^{\% * \%}\right.$ and $0.75^{* \% *}$, respectively). The difference between the values of $r$ for the last two soil groups was not statistically significant as tested by the z-transformation test (SNEDECOR and COCHRAN 1972), and the coefficients hardly changed when the effect of $\mathrm{Fe}$ was excluded.

Because the distribution of secondary $\mathrm{P}$ in $\mathrm{NH}_{4} \mathrm{~F}$ and $\mathrm{NaOH}$ soluble forms seemed to be markedly controlled by the ratio $\mathrm{Al} / \mathrm{Fe}$, the partial correlation coefficients for the relationship between water soluble $\mathrm{P}$ and a particular 
fraction were calculated by eliminating the effect of corresponding sorptive component. The values of $r$, given in the following, were higher than the total correlation coefficients (cf. Table 3 ):

\begin{tabular}{|c|c|c|}
\hline & $\mathrm{NH}_{4} \mathrm{~F}-\mathrm{P} \cdot \mathrm{Al}$ & $\mathrm{NaOH}-\mathrm{P}_{\mathrm{Fe}}$ \\
\hline Heavy clays & $0.81^{* * 4}$ & $0.63^{\text {th }}$ \\
\hline Coarser clays & $0.87^{* * \#}$ & 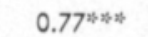 \\
\hline Non-clay soils & $0.91^{* n *}$ & $0.57^{4+4 *}$ \\
\hline All samples & $0.86^{\text {*n+1/4 }}$ & $0.68^{* * 4 *}$ \\
\hline
\end{tabular}

The amorphous $\mathrm{Al}$ and $\mathrm{Fe}$ oxides and the phosphates bound by them seem to be of great importance in controlling the level of easily soluble $\mathrm{P}$ in soils. Therefore the dependence of water extractable $\mathrm{P}$ on the molar ratios $\mathrm{NH}_{4} \mathrm{~F}-\mathrm{P} / \mathrm{Al}$ and $\mathrm{NaOH}-\mathrm{P} / \mathrm{Fe}$ was calculated. As these molar ratios seemed to correlate with each other, the corresponding partial correlation coefficients, too, were calculated (Table 4 ). The results imply that water soluble $\mathrm{P}$ is primarily controlled by the ratio $\mathrm{NH}_{4} \mathrm{~F}-\mathrm{P} / \mathrm{Al}$. This factor was found to explain $77 \%$ of the variation in the $\mathrm{NH}_{4} \mathrm{Cl}-\mathrm{P}$.

Table 4. Total and partial correlation coefficients for the relation between the water soluble $\mathrm{P}(1)$, molar ratio $\mathrm{NH}_{4} \mathrm{~F}-\mathrm{P} / \mathrm{Al}$ (2), and molar ratio $\mathrm{NaOH}-\mathrm{P} / \mathrm{Fe}$ (3).

\begin{tabular}{|c|c|c|c|c|}
\hline & $r_{12}$ & $r_{13}$ & $r_{12.3}$ & $r_{13.2}$ \\
\hline Heavy clays & $0.89^{*-4 * 4}$ & $0.63^{\text {n+m }}$ & $0.82^{\text {wnkn}}$ & ns \\
\hline Coarser clays & $0.93^{\text {n+n }}$ & $0.77^{*+4 / 4}$ & $0.82^{\text {कास }}$ & ns \\
\hline Non-clay soils & $0.95^{\text {H*H }}$ & $0.54^{\text {math }}$ & $0.93^{\text {*क* }}$ & ns \\
\hline All samples & $0.93^{\text {\#\#\# }}$ & $0.66^{\text {whH }}$ & $0.88^{\text {*\#\# }}$ & ns \\
\hline
\end{tabular}

$\mathrm{ns}=$ not significant

Further, the relationship between water soluble $\mathrm{P}$ and soil characteristics was investigated by the regression analysis. The coefficient of multiple determination $\mathrm{R}^{2}$ for the equation with the variables soil $\mathrm{pH}$ as well as the ratios $\mathrm{NH}_{4} \mathrm{~F}-\mathrm{P} / \mathrm{Al}$ and $\mathrm{NaOH}-\mathrm{P} / \mathrm{Fe}$ was calculated, but $\mathrm{NH}_{4} \mathrm{~F}-\mathrm{P} / \mathrm{Al}$ was the only statistically significant variable. Soil $\mathrm{pH}$ explained merely $0.4 \%(\mathrm{P}=0.05)$ and $\mathrm{NaOH}-\mathrm{P} / \mathrm{Fe}$ not at all the variation in water extractable $\mathrm{P}$. Thus, in 103 samples the relationship between water soluble $\mathrm{P}$ as $\mathrm{mmol} / \mathrm{kg}(\mathrm{y})$ and the ratio of $\mathrm{NH}_{4} \mathrm{~F}$ soluble $\mathrm{P}$ to oxalate extractable $\mathrm{Al}$ as $\mathrm{mmol} / \mathrm{kg}\left(\mathrm{x}_{1}\right)$ was found to conform to the following regression equation (the soil-solution ratio $1: 60)$ :

$$
\begin{array}{ll}
y=-0.209+9.792 x_{1} \quad & R^{2}=0.87 \\
& S=0.201 \\
& s_{b}=0.009
\end{array}
$$

If the $\mathrm{NH}_{4} \mathrm{~F}-\mathrm{P}$ and $\mathrm{Al}$ dissolved in oxalate solution were used as independent variables, the value of the coefficient of multiple determination $\mathrm{R}^{2}$ would have lowered to 0.75 . 


\section{Discussion}

The quantities of water soluble $\mathrm{P}$ varied very largely; from about $0.4 \mathrm{~kg}$ to $235 \mathrm{~kg}$ per one hectare, surface layer $0-20 \mathrm{~cm}$ corresponding to bulk density $1 \mathrm{~kg} / \mathrm{dm}^{3}$. The soil sample extremely rich in water soluble $P$ was a very heavily limed muddy fine sand. Generally, more P was extracted from the non-clay soils than the clay soils. This can be expected, because Finnish soils are found to retain $\mathrm{P}$ the more effectively the finer the soil material is (KAILA 1965, HARTIKAINEN 1979). The greater retention ability of fine textured soils is primarily due to their higher content of active sorption components. Also in the present material the heavy clay soils contained more abundantly oxalate extractable $\mathrm{Al}$ and $\mathrm{Fe}$ than the soils in the other groups.

The nature of $\mathrm{P}$ bonding seemed to be of major importance in controlling the extractability of soil $\mathrm{P}$ into water. It was found that, the later phase of the extraction sequence a given fraction represented, the more weakly it seemed to be associated with the water soluble resources. The $\mathrm{NH}_{4} \mathrm{Cl}-\mathrm{P}$ correlated most closely because it is obviously included in water soluble reserves. Thus, it reflects the soil P status alike with the water extractable P. SHARPLEY et al. (1977), for instance, found that the mean concentration of dissolved inorganic phosphate in each of several surface runoff events from established pasture was closely correlated with the amounts of inorganic $\mathrm{P}$ extracted by $0.1 \mathrm{M} \mathrm{NaCl}$ from the top soil prior to the event.

The results of the correlation analyses illustrate the role of the $\mathrm{NH}_{4} \mathrm{~F}$ soluble fraction in determining the concentration of phosphate in the soil solution. However, as expected on the basis of a previous study (HARTIKAINEN 1979), the supplying power of this fraction seems to be controlled by the amount of corresponding sorption component. Hence, the water soluble $\mathrm{P}$ was most closely related to the molar ratio $\mathrm{NH}_{4} \mathrm{~F}-\mathrm{P} / \mathrm{Al}$.

But, in spite of the striking correlation $(r=0.93 \% \%, n=103)$, the role of this ratio as well as that of the $\mathrm{NH}_{4} \mathrm{~F}$-fraction should not be overestimated. First, it should be taken into consideration that this index does not include other anions (silicate, organic anions, etc.) competing with phosphate for sorptive surface, and so it does not describe actual conditions in soils. Second, at a certain "saturation degree", one soil sample may contain smaller amounts of free active sorption components than another with higher absolute content of sorption agents. In the present material, for instance, the heavy clay soil sample exceptionally rich in oxalate soluble Al had the second highest molar ratio within the group, but the second lowest quantity of water soluble $\mathrm{P}$. Third, it is obvious that, in addition to $\mathrm{NH}_{4} \mathrm{~F}-\mathrm{P}$ supposed to be bound by $\mathrm{Al}$, also the $\mathrm{NaOH}-\mathrm{P}$ likely bound by $\mathrm{Fe}$ is of significance. Partly this results from the fact that there is no specific reagent to distinguish specificly these P forms (e.g. BROMFIELD 1970, KURMIES 1972), but other factors, too, are involved.

It is true that phosphate oxygen forms a stronger bond with $\mathrm{Fe}$ than with $\mathrm{Al}$ (cf. AURA 1980). The significance of $\mathrm{Al}$ bound phosphate is established by many investigators (MacKENZIE 1962, DUNBAR and BAKER 1965, MURRMANN and PEECH 1969). However, according to HINGSTON et al. (1974) it is 
possible with progressing desorption the bonding pattern of remaining phosphate to change and more stabile surface complexes to form. Thus, it can be assumed that in proportion, as phosphate is desorbed from the surface of $\mathrm{Al}$ oxides, the bonding strength of the remaining phosphate increases and converges that of phosphate bound by $\mathrm{Fe}$ oxides. As a result, at a certain stage also Fe bound phosphate is able to participate in desorption reactions. Consequently, this stage is reached the sooner the more phosphate is sorbed on Fe oxides. This theory involves the decisive role of sorptive agents and the relationship between $\mathrm{P}$ intensity and capacity in soils.

Part of the $\mathrm{P}$ released from $\mathrm{NaOH}$ soluble fraction under reduced circumstances or in the presence of complexing agent can be resorbed into $\mathrm{NH}_{4} \mathrm{~F}$ extractable form (HARTIKAINEN 1979). Also in the water treatment the rate of desorption of $\mathrm{Fe}$ bound $\mathrm{P}$ may be decreased by a possible resorption. If this is true the final desorption would take place through the $\mathrm{NH}_{4} \mathrm{~F}$ fraction. In any case, it can be concluded in accordance with the conception of ELRASHIDI and LARSEN (1978) that both Al bound and Fe bound P control the phosphate concentration in the soil solution. This assumption is supported also by the unpublished data obtained by the author in a test with soils very rich in easily soluble $\mathrm{P}$. They showed that $\mathrm{NH}_{4} \mathrm{~F}$ as well as $\mathrm{NaOH}$ soluble reserves were attacked by water extraction.

According to the current conception the $\mathrm{P}$ in $\mathrm{NH}_{4} \mathrm{~F}$ and $\mathrm{NaOH}$ soluble fractions originates from reserves bound onto the surfaces of hydrated oxides rather than from specific chemical compounds. Therefore these fractions are more able to participate in desorption than the $\mathrm{H}_{2} \mathrm{SO}_{4}$ and reductant soluble ones, more likely originating from discrete chemical compounds. With progressing weathering the $\mathrm{H}_{2} \mathrm{SO}_{4}-\mathrm{P}$ may have only an indirect and extremely slow influence on the water extractable P. In some soils quite a great portion of the total inorganic $\mathrm{P}$ was composed of the reductant soluble reserves. The results of the present study give intimations that $\mathrm{Mn}$ may, along with $\mathrm{Fe}$, participate in reactions removing $\mathrm{P}$ from active $\mathrm{P}$ cycle to the form difficult to dissolve and indirectly affect quantities of $\mathrm{P}$ soluble in water. In the litterature there is, however, scarce, if any knowledge about the role of $\mathrm{Mn}$ in the soil $\mathrm{P}$ cycle. Manganese may be of some importance especially in the reactions of sedimentary $P$.

Because the availability of secondary $\mathrm{P}$ seems to be dependent on the amount of sorption components, the suitability of strong reagents able to remove most of the adsorbed $\mathrm{P}$ is questionable. Besides, some other factors have shown to limit the reliability of many common extractants. Van der PAAUW (1969), for instance, has reported that the P concentration in the potato tops correlated closely and independently of soil $\mathrm{pH}$ with water soluble P, but with P-AL (according EGNÉR-RIEHM-DOMINGO) only within a narrow $\mathrm{pH}$ range. Also in the present investigation there existed only slight, if any, dependence between water soluble $\mathrm{P}$ and soil $\mathrm{pH}$. According to common knowledge, the availability of soil $\mathrm{P}$ improves with decreasing soil acidity. The significance of $\mathrm{pH}$ on desorption is, however, found to lessen as the amount of secondary $\mathrm{P}$ in the soil increases (HARTIKAINEN 1981 a). Thus, the importance of $\mathrm{pH}$ varies in different soils. Further, on the basis of 
earlier studies (KAILA 1965, HARTIKAINEN 1981a) it can be assumed that the nature of $\mathrm{P}$ bonding, determining the extractability, is somewhat connected with soil $\mathrm{pH}$.

In the heavy clay soils the ratio of $\mathrm{NH}_{4} \mathrm{~F}-\mathrm{P}$ to $\mathrm{NaOH}-\mathrm{P}$ tended to become greater with increasing content of organic carbon in the soil. This may partly be due to the fact that in soil, $\mathrm{Al}$ participates less in complexation reactions than $\mathrm{Fe}$ (e.g. SCHNITZER and SKINNER 1963). In addition, the complexation reactions have been found to remove $\mathrm{P}$ from the $\mathrm{NaOH}$ soluble form to the $\mathrm{NH}_{4} \mathrm{~F}$ extractable one (HARTIKAINEN 1979, $1981 \mathrm{~b}$ ). But, in accordance with the results of van der PAAUW (1969), the water soluble P was not dependent on the content of organic carbon in soil.

On the basis of what is stated above it can be concluded that water extractable P illustrates the "effective P status" which is determined by the quantity and quality of sorption components, soil $\mathrm{pH}$ and the content of organic matter. Thus, these factors indirectly control the magnitude of easily soluble resources by affecting the nature of $\mathrm{P}$ bonding which, in turn, seems to be of decisive importance in water extraction.

Water extraction seems to be a suitable method for estimating the immediate P loading into waters caused by eroded soil and for estimating amounts of $\mathrm{P}$ possible to be carried out from fields as dissolved in runoff waters. It is obvious, however, that a relatively low surface layer is able to supply the runoff or flood water with $\mathrm{P}$, because the diffusion of $\mathrm{P}$ in soil is very slow (LEWIS and QUIRK 1967, KUNISHI and TAYLOR 1975).

The factors found to govern the water soluble P in soils may, to some extent, determine also the $\mathrm{P}$ exchange between the lake sediment and overlying water under aerobic conditions. If this assumption is valid, in addition to $\mathrm{Fe}$ bound phosphates also $\mathrm{Al}$ and $\mathrm{P}$ bound by $\mathrm{Al}$ are important factors in the P budget of lakes, as concluded earlier by HARTIKAINEN (1979).

Acknowledgement. The author wishes to thank the Maj and Tor Nessling Foundation for supporting this study financially.

\section{References}

ANON. 1969. Juoma- ja talousveden tutkimusmenetelmät. Elintarviketutkijain Seura. 169 p. Helsinki.

AURA, E. 1978. Determination of available soil phosphorus by chemical methods. J. Scient. Agric. Soc. Finl. 50: 305-316.

- 1980. Oxygen as an exchangeable ligand in soil. J. Scient. Agric. Soc. Finl. 52: 34-44.

BROMFIELD, S. M. 1970. The inadequacy of corrections for resorption of phosphate during the extraction of aluminium-bound soil phosphate. Soil Sci. 109: 338-390.

DUNBAR, A. D. \& BAKER, D. E. 1965. Use of isotopic dilution in a study of inorganic phosphorus fractions from different soils. Soil Sci. Soc. Amer. Proc. 29: 259-262.

ELRASHIDI, M. A. \& LARSEN, S. 1978. The effect of phosphate addition on the solubility of phosphate in soil. Plant and Soil 50: 585-594. 
GRAHAM, E. R. 1948. Determination of soil organic matter by means of a photoelectric colorimeter. Soil Sci. 65: 181-183.

HARTIKAINEN, H. 1979. Phosphorus and its reactions in terrestrial soils and lake sediments. J. Scient. Agric. Soc. Finl. 51: 537-624.

- 1981 a. Effect of decreasing acidity on the extractability of inorganic soil phosphorus. J. Scient. Agric. Soc. Finl. 53: 16-26.

- 1981 b. Uptake of soil P, Al, Fe, Mn, Mg and Ca by Italian rye grass (Lolium multiflorum Lam.) induced by synthetic chelating agent. J. Scient. Agric. Soc. Finl. 53: 152-160.

HINGSTON, F. J., POSNER, A. M. \& QUIRK, J. P. 1974. Anion adsorption by goethite and gibbsite. II Desorption of anions from hydrous oxide surfaces. J. Soil Sci. 25: 16-26.

KAILA, A. 1955. Studies on the colorimetric determination of phosphorus in soil extracts. Acta Agr. Fenn. 83: 25-47.

- 1965. Effect of liming on the mobilization of soil phosphorus. J. Scient. Agric. Soc. Finl. 37: 243-254.

KUNISHI, H. M. \& TAYLOR, A. W. 1975. The effect of phosphate applications on the diffusion coefficients and available phosphate in an acid soil. J. Soil Sci. 26: 267-277.

KURMIES, B. 1972. Zur Fraktionierung der Bodenphosphate. Phosphorsäure 29: 118-151.

LEWIS, D. G. \& QUIRK, J. P. 1967. Phosphate diffusion in soil and uptake by plants. I Self-diffusion of phosphate in soils. Plant and Soil 26: 99-118.

MacKENZIE, A. F. 1962. Inorganic soil phosphorus fractions of some Ontario soils as studied using isotope exchange solubility criteria. Can. J. Soil Sci. 42: 150-156.

MURRMANN, R. P. \& PEECH, M. 1969. Effect of pH on labile and soluble phosphate in soils. Soil Sci. Soc. Amer. Proc. 33: 205-210.

PAAUW, F. van der. 1969. Entwicklung und Verwertung einer neuen Wasserextraktionsmethode für die Bestimmung der pflanzenaufnehmbaren Phosphorsäure. Landwirtsch. Forsch. 23/II. Sonderheft: $102-109$.

- 1971. An effective water extraction method for the determination of plant-available soil phosphorus. Plant and Soil 34: 467-481.

SCHACHTSCHABEL, P. \& BEYME, B. 1980. Löslichkeit des anorganischen Bodenphosphors und Phosphatdüngung. Z. Pfl. ern. Düng. Bodenk. 143: 306-316.

SCHARPLEY, A. N., TILLMAN, R. W. \& SYERS, J. K. 1977. Use of laboratory extraction data to predict losses of dissolved inorganic phosphate in surface runoff and tile drainage. J. Environ. Qual. 6: 33-36.

SCHNITZER, M. \& SKINNER, S. I. M. 1963. Organo-metallic interactions in soils: 1. Reactions between a number of metall ions and the organic matter of a podzol $\mathrm{B}_{\mathrm{h}}$ horizon. Soil Sci. 96: $86-93$.

SISSINGH, H. A. Analytical technique of the Pw method, used for the assesment of the phosphate status of arable soils in the Netherlands. Plant and Soil 34: 483-486.

SNEDECOR, G. W. \& COCHRAN, W. G. 1972. Statistical methods. 593 p. Ames.

Ms received April 16, 1982. 


\section{Vesiliukoinen fosfori ja siihen vaikuttavat tekijät suomalaisissa kivennäis- maissa}

\section{Helinä Hartikainen}

Helsingin yliopiston maanviljelyskemian laitos, 00710 Helsinki 71

Vesiuuttoisen fosforin määrä vaihteli 104 pintamaanäytteen aineistossa $0.2 \mathrm{mg}: s t a 117.8 \mathrm{mg}$ :aan maakiloa kohti. Aitosavista uuttui keskimäärin vähemmän fosforia $(4.8 \pm 2.2 \mathrm{mg} / \mathrm{kg}) \mathrm{kuin}$ muista savimaista $(12.8 \pm 4.6 \mathrm{mg} / \mathrm{kg})$ sekä hiesu- ja hietamaista $(13.3 \pm 7.2 \mathrm{mg} / \mathrm{kg})$.

Vesiuutto näyttää kuvaavan maan "efektiivistä" fosforitilaa. Uuttuminen ei rïppunut maan pH:sta eikä orgaanisen aineksen pitoisuudesta. Nämä tekijät vaikuttavat todennäköisesti fosforin sitoutumistapaan, jolla puolestaan näyttää olevan ratkaiseva merkitys vesiliukoisen fosforin kannalta.

Tietyn P-fraktion merkitys vesiliukoisen fosforin lähteenä rïppuu kuitenkin myös k.o. fraktiota vastavan sorptiokomponentin määrästä. Desorptiotaipumus pyrki lisääntymään, kun fraktion $\mathrm{P}$-määrän ja oksalaatilla uutetun sorptiokomponentin suhde kasvoi. Kiinteimmin vesiuuttoinen $\mathrm{P}$ korreloi $\mathrm{NH}_{4} \mathrm{~F}-\mathrm{P}: \mathrm{n}$ ja Al:n moolisuhteen kanssa $\left(r=0.93^{\text {햐갸 }}, n=103\right)$. Esitetyn teorian mukaan desorption edistyessä alkaa fosforia mobilisoitua myös $\mathrm{NaOH}$-liukoisista varoista, joiden merkitys on ilmeisesti sitä tuntuvampi mitä suurempi suhde $\mathrm{NaOH}-\mathrm{P} / \mathrm{Fe}$ on. Näin ollen tulokset antavat viitteitä myös fosforin intensiteetin ja kapasiteetin suhteeseen vaikuttavista tekijöistä. Muilla epäorgaanisen fosforin fraktioilla ei ilmeisesti ole merkitystä vesiuuttoisen fosforin kannalta tai vaikutus on epäsuora ja hyvin hidas. 